\title{
ANALISIS PENGARUH TINGKAT PENGANGGURAN TERBUKA, INDEKS PEMBANGUNAN MANUSIA, DAN UPAH MINIMUM TERHADAP JUMLAH PENDUDUK MISKIN DI INDONESIA TAHUN 2011-2015
}

\author{
Shinta Setya Ningrum \\ Badan Pertanahan Nasional Kabupaten Banyuwangi \\ Email: shintasetyaningrum26@gmail.com
}

\begin{abstract}
Poverty continues to be a major problem of the world, especially in developing Indonesia. The study has the objective of testing and analyzing Open Unemployment Rate, Human Development Index, and Minimum Wage for Poor People in Indonesia Year 2011-2015. This type of data uses secondary data obtained from Indonesian BPS and also the journal as research support. This research uses panel data model and use eviews9. The regression result shows that the value of Adjusted R-Square is 0.993546 which means 99.35 percent of the variation of the poor population $(Y)$ can be explained by the independent variables in the statistical models that TPT, IPM, and minimum wage. While 0.65 percent of the variation in the number of poor people $(Y)$ is explained by factors outside the model.
\end{abstract}

Keywords: Human Development Index, Minimum wages, Number of Poor, Open Unemployment Rate

\begin{abstract}
Abstrak
Kemiskinan terus menjadi masalah utama dunia, khususnya di Indonesia yang menjadi negara berkembang. Penelitian memiliki tujuan menguji dan menganalisis Tingkat Pengangguran Terbuka, Indeks Pembangunan Manusia, dan Upah Minimum terhadap Jumlah Penduduk Miskin di Indonesia Tahun 20112015. Jenis data menggunakan data sekunder yang diperoleh dari BPS Indonesia dan juga jurnal sebagai pendukung penelitian. Penelitian ini menggunakan model data panel dan menggunakan eviews9. Hasil regresi menunjukkan bahwa nilai Adjusted R-Square sebesar 0,993546 yang artinya 99,35 persen variasi jumlah penduduk miskin (Y) dapat dijelaskan oleh variabel independen dalam model statistik yaitu TPT, IPM, dan upah minimum. Sedangkan 0,65 persen variasi dari jumlah penduduk miskin (Y) dijelaskan oleh faktor-faktor diluar model.
\end{abstract}

Kata kunci: Indeks Pembangunan Manusia, Jumlah Penduduk Miskin, Tingkat Pengangguran Terbuka, Upah Minimum

\section{PENDAHULUAN}

Kemiskinan terus menjadi masalah utama dunia, khususnya di Indonesia yang menjadi negara berkembang. Kemiskinan yang terjadi pada suatu negara dilihat menjadi permasalahan yang serius, karena pada masa sekarang kemiskinan membuat masyarakat 
Indonesia tidak bisa mencukupi kehidupannya.

$$
\text { Menurut M.Nasir }
$$
permasalahan kemiskinan merupakan permasalahan kompleks dan multidimensi. Kemiskinan di Indonesia disebabkan oleh berbagai faktor, yaitu tingkat upah kurang, tingkat pengangguran yang tinggi, dan IPM yang masih kurang. Dapat dikatakan miskin apabila belum bisa mencukupi kebutuhannya atau belum berpenghasilan.

$$
\text { Pengangguran merupakan }
$$

kondisi seseorang tergolong angkatan kerja dan yang menginginkan pekerjaan tetapi belum memperoleh pekerjaan tersebut, Sukirno (1997).

IPM membahas penduduk pada suatu wilayah memiliki kesempatan memperoleh hasil pembangunan dari haknya untuk mendapatkan pendidikan, pendapatan, kesehatan. Selain itu IPM juga digunakan mengklasifikasikan apakah sebuah negara termasuk dalam kategori negara maju, negara berkembang atau negara terbelakang. Hal tersebut menjadi tolak ukur mengetahui pengaruh kebijakan ekonomi pada suatu negara.
Upah adalah sumber penghasilan, bila sumber penghasilan turun atau tetap maka kesejahteraan juga turun atau tetap dan itu juga pasti akan mempengaruhi tingkat kemiskinan. Upah yang diberikan nyatanya secara riil nilainya cukup rendah meskipun secara nominal angkanya cukup tinggi.

Tujuan penelitian ini yaitu untuk menguji dan menganalisis pengaruh Tingkat Pengangguran Terbuka, Indeks Pembangunan Manusia, dan Upah Minimum terhadap Jumlah Penduduk Miskin di Indonesia Tahun 2011-2015.

\section{METODE PENELITIAN}

Digunakan teknik dokumentasi yang merupakan pengumpulan data tertulis melalui instansi yang terkait, yaitu BPS Indonesia. Variabel penelitian merupakan sesuatu bentuk memperoleh informasi kemudian ditarik kesimpulannya, Sugiyono (2011).

Adapun definisi operasional variabel yaitu sebagai berikut:
1. Kemiskinan
(Y) adalah ketidakmampuan mencukupi kebutuhan dasar. Data jumlah penduduk miskin menggunakan 
data jumlah penduduk miskin Indonesia tahun 2011-2015. (dalam persen). Sumber : BPS Indonesia.

2. TPT (X1) adalah persentase penduduk dalam angkatan kerja yang tidak mempunyai mata pencaharian dan sedang mencari pekerjaan di masing-masing provinsi. (dalam persen). Sumber : BPS Indonesia.

3. Indeks Pembangunan Manusia (X2) yaitu ukuran capaian pembangunan manusia berbasis sejumlah komponen dasar kualitas hidup. Data IPM menggunakan data IPM Indonesia tahun 20112015. (dalam persen). Sumber : BPS Indonesia.

4. Upah Minimum (X3) merupakan sumber penghasilan, bila sumber penghasilan turun atau tetap maka kesejahteraan juga turun atau tetap dan itu juga pasti akan mempengaruhi tingkat kemiskinan. Data yang dipakai yaitu upah minimum Indonesia tahun 2011-2015. (dalam Rupiah). Sumber : BPS Indonesia.

Pada penelitian ini digunakan model data panel. Data panel yaitu data yang mempunyai dua dimensi yaitu individu (cross section) dan waktu (time series), dimana setiap unit cross section (individu) diulang dalam beberapa periode waktu.

Kelebihannya yaitu dapat mengakomodasi keheterogenan antar individu secara eksplisit. Selain itu, penggabungan antara individu (cross section) dan waktu (time series) membuat data panel menjadi lebih informatif, memperbanyak derajat bebas dan lebih efisien. Persamaannya, seperti berikut:

$Y_{i}=\beta_{0}+\beta_{1} X_{1 i}+\beta_{2} X_{2 i}+\beta_{3} X_{3 i}+e_{i}(1)$

Dimana :

$Y_{i}=$ jumlah penduduk miskin

$\beta_{0}=$ intersep

$X_{1 i}=\mathrm{tpt}$

$X_{2 i}=\mathrm{ipm}$

$X_{3 i}=$ upah minimum

$\beta_{1}, \beta_{2}, \beta_{3}=$ koefisien regresi

$\boldsymbol{e}_{\boldsymbol{i}}=$ error term

Ada tiga model data panel, yaitu :

1. Pooled/Common Effects (CE)

Pooled/common effects adalah model paling sederhana yang mengasumsikan bahwa tidak ada keheterogenan antar individu yang terobservasi (intersep sama). Estimasi 
parameter pooled model menggunakan metode OLS.

2. $\quad$ Fixed Effects (FE)

Model Fixed Effects, intersep pada regresi dapat dibedakan antar individu karena setiap individu dianggap mempunyai karakteristik tersendiri.

3. Random Effects (RE)

Random Effects merupakan model yang terdapat hubungan error term karena berubahnya waktu karena perbedaan observasi dapat diatasi menggunakan pendekatan model komponen error.

Dari ketiga pendekatan diatas ditentukan dengan Uji Chow dan Uji Hausman. Selanjutnya, uji hipotesis (uji t-statistik, uji F-statistik, koefisien determinasi) untuk mengetahui kebaikan modelnya.

\section{PEMBAHASAN}

Berikut merupakan uji Fixed Effects yang digunakan sebagai acuan untuk mengerjakan uji hipotesisnya.

\section{Tabel 1. Fixed Effects}

Dependent Variable: Y

Method: Panel EGLS (Cross-section weights)

Date: 04/03/17 Time: 22:33

Sample: 20112015

Periods included: 5

Cross-sections included: 33

Total panel (balanced) observations: 165

\begin{tabular}{lllll}
\hline \hline Variable & \multicolumn{2}{c}{ Coefficient Std. Error } & t-Statistic & Prob. \\
\hline \hline C & 68.39714 & 9.082023 & 7.531047 & 0.0000 \\
X1 & 0.073014 & 0.022934 & 3.183636 & 0.0018 \\
X2 & -0.865177 & 0.138702 & -6.237663 & 0.0000 \\
X3 & $1.33 E-06$ & $2.57 \mathrm{E}-07$ & 5.163386 & 0.0000 \\
\hline \hline & \multicolumn{5}{c}{ Effects Specification } \\
\hline
\end{tabular}

Cross-section fixed (dummy variables)

\begin{tabular}{|c|c|c|c|}
\hline & \multicolumn{3}{|c|}{ Weighted Statistics } \\
\hline \multirow{5}{*}{$\begin{array}{l}\text { R-squared } \\
\text { Adjusted R-squared } \\
\text { S.E. of regression } \\
\text { F-statistic } \\
\text { Prob(F-statistic) }\end{array}$} & \multicolumn{2}{|c|}{0.994923 Mean dependent var } & 18.50421 \\
\hline & \multicolumn{2}{|c|}{0.993546 S.D. dependent var } & 11.53453 \\
\hline & \multicolumn{2}{|c|}{ 0.743230 Sum squared resid } & 71.25836 \\
\hline & \multicolumn{2}{|c|}{ 722.2959 Durbin-Watson stat } & 1.676583 \\
\hline & \multicolumn{3}{|l|}{0.000000} \\
\hline & \multicolumn{3}{|c|}{ Unweighted Statistics } \\
\hline R-squared & 0.989022 & Mean dependent var & 12.25048 \\
\hline Sum squared resid & 74.50472 & Durbin-Watson stat & 1.474326 \\
\hline
\end{tabular}

Sumber: Output Eviews 9 
Berdasarkan hasil estimasi untuk Fixed Effects secara statistik variabel TPT (X1), IPM (X2), Upah Minimum (X3) signifikan. Dimana nilai probabilitas TPT (X1) sebesar 0,0018, nilai probabilitas IPM (X2) sebesar 0,0000, dan nilai probabilitas Upah Minimum (X3) sebesar 0,0000 $<\propto 0,05$.

\section{Tabel 2. Uji Chow}

Redundant Fixed Effects Tests

Equation: FE

Test cross-section fixed effects

Effects Test Statistic $\quad$ d.f. $\quad$ Prob.

Cross-section F462.605058 (32,129) 0.0000

Sumber: Output Eviews 9

$$
\text { Berdasarkan Uji Chow, }
$$

diperoleh nilai Prob.F $=0,000$. Nilai Prob.F $<\propto 0,05$, menerima $\mathrm{H}_{1}$. Dengan demikian, FE lebih tepat digunakan.

\section{Tabel 3. Uji Hausman}

Correlated Random Effects -

Hausman Test

Equation: RE

Test cross-section random effects

Chi-Sq. Chi-Sq.

Test Summary Statistic d.f. Prob.

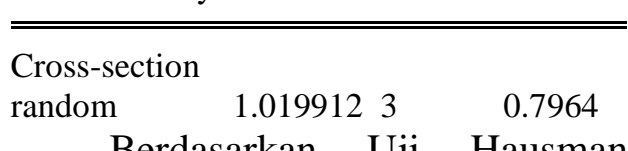
Berdasarkan Uji Hausman, diperoleh nilai Prob.F $=0,7964$. Nilai Prob.F $>\propto 0,05$, gagal menolak $\mathrm{H}_{0}$. FE lebih tepat digunakan.

Berdasarkan hasil pemilihan model diatas maka digunakan Fixed Effects. Selanjutnya akan dianalisis lebih lanjut dengan menggunakan uji hipotesis (uji t-statistik, uji Fstatistik, dan uji koefisien determinasi).

Tabel 4. Nilai Hitung $t$ dan Nilai Hitung Tiap Variabel

\begin{tabular}{lllll}
\hline $\begin{array}{l}\text { Vari } \\
\text { able }\end{array}$ & $\begin{array}{l}\text { Coefficie } \\
\text { nt }\end{array}$ & Std. Error & t-Statistic & Prob. \\
\hline $\mathrm{C}$ & 68.39714 & 9.082023 & 7.531047 & 0.0000 \\
\hline $\mathrm{X} 1$ & 0.073014 & 0.022934 & 3.183636 & 0.0018 \\
\hline $\mathrm{X} 2$ & -0.865177 & 0.138702 & -6.237663 & 0.0000 \\
\hline $\mathrm{X} 3$ & $1.33 \mathrm{E}-06$ & $2.57 \mathrm{E}-07$ & 5.163386 & 0.0000 \\
\hline \multicolumn{5}{l}{ Sumber: Output pada Eviews 9}
\end{tabular}

Dari tabel diatas dapat dilihat bahwa nilai probabilitas TPT (X1) sebesar $0,0018<0,05$ maka variabel $\mathrm{X} 1$ signifikan terhadap (Y). TPT berpengaruh positif dan signifikan terhadap jumlah penduduk miskin Indonesia tahun 2011-2015. Nilai probabilitas IPM (X2) sebesar $0,0000<0,05$ maka variabel $\mathrm{X} 2$ signifikan terhadap (Y). IPM berpengaruh positif dansignifikan terhadap jumlah penduduk miskin Indonesia tahun 2011-2015. Nilai probabilitas upah minimum (X3) sebesar $0,0000<0,05$ maka variabel X3 signifikan terhadap (Y). Upah minimum berpengaruh positif dan 
signifikan terhadap jumlah penduduk miskin Indonesia tahun 2011-2015.

\section{Uji F-statistik}

Berdasarkan hasil pengamatan data diatas diketahui bahwa nilai $\mathrm{df}_{1}$ sebesar 3 dan $\mathrm{df}_{2}=\mathrm{n}-\mathrm{k}-1$ sebesar $161 \quad(2,66)$ pada $\propto(0.05)$. $F_{\text {hitung }}(722,2959)>F_{\text {tabel }}(2,66)$ dengan demikian $\mathrm{H}_{1}$ diterima karena $\mathrm{F}_{\text {hitung }}>\mathrm{F}_{\text {tabel }}$ artinya bahwa variabel TPT (X1), IPM (X2), dan Upah Minimum (X3) secara bersama-sama signifikan mempengaruhi (Y) pada tingkat kepercayaan $95 \%$.

\section{Uji R-Squared}

Nilai Adjusted R-Square adalah sebesar 0,993546 yang artinya 99,35 persen variasi (Y) dapat dijabarkan pada model statistik yaitu TPT, IPM, dan upah minimum. Sedangkan 0,65 persen variasi dari (Y) dijelaskan oleh faktor-faktor diluar model.

\section{Pengaruh TPT dengan Jumlah}

\section{Penduduk Miskin}

TPT berpengaruh positif dan signifikan terhadap jumlah penduduk miskin Indonesia tahun 2011-2015. Nilai koefisien TPT sebesar 0,073014 memiliki arti bahwa setiap kenaikan TPT sebesar 1 persen dapat meningkatkan jumlah penduduk miskin sebesar 0,073014 persen dan sebaliknya.

Indikator pengangguran dipilih berdasarkan kenyataan bahwa indikator tersebut terkait tingkat pendapatan. Seorang pengangguran tentunya tidak mempunyai penghasilan dari pekerjaan. Kebutuhan masyarakat yang cukup tinggi dan bermacam-macam tersebut membuat mereka bekerja keras mencukupi kebutuhannya.

Yang bisa dilakukan yaitu bekerja untuk mendapatkan suatu penghasilan, jika tidak bekerja mereka tidak mencukupi kebutuhannya secara baik. Ketika kebutuhan tidak terpenuhi secara baik, dampaknya mereka akan menjadi miskin dan mengakibatkan membengkaknya jumlah penduduk miskin.

Pengaruh TPT dan kemiskinan ini juga sesuai dengan penelitian oleh Mufid (2014) yang menunjukan bahwa variabel TPT positif dan berpengaruh signifikan terhadap (Y). Hal tersebut menyebabkan penduduk berusaha untuk mempersiapkan membuka usaha sendiri, selain itu juga ada yang sedang menunggu untuk memulai bekerja yang 
termasuk dalam kategori pengangguran terbuka.

Jika kita tinjau dari perseorangan, pengangguran dapat menyebabkan kekacauan pada bidang ekonomi dan sosial. Apabila pengangguran di suatu negara buruk, akan menimbulkan kekacauan politik dan sosial. Hal tersebut menyebabkan efek buruk untuk kehidupan dan pembangunan ekonomi jangka panjang.

\section{Pengaruh IPM dengan Jumlah}

\section{Penduduk Miskin}

IPM berpengaruh negatif dan signifikan terhadap (Y). Nilai koefisien IPM sebesar -0,865177, setiap naiknya IPM sebesar 1 persen dapat mengurangi jumlah penduduk miskin sebesar 0,865177 persen dan sebaliknya.

Pengaruh IPM ini juga sesuai dengan penelitian oleh Mufid (2014) yang menunjukkan menurunnya kemiskinan saat IPM naik mengakibatkan naiknya produktifitas kerja penduduk yang menaikkan penghasilan.

Dengan meningkatnya suatu pendapatan akan menyebabkan masyarakat mampu mencukupi kebutuhannya serta dapat mengurangi tingkat kemiskinan. Hasil regresi juga ditunjang dengan naiknya IPM Indonesia dari tahun ke tahun sehingga meningkatnya IPM dapat mengurangi penduduk miskin Indonesia.

\section{Pengaruh Upah Minimum dengan Jumlah Penduduk Miskin}

Upah minimum berpengaruh positif dan signifikan terhadap (Y). Nilai koefisien upah minimum sebesar 1.33E-06 menunjukkan setiap kenaikan upah minimum sebesar 1 juta rupiah maka dapat meningkatkan $(\mathrm{Y})$ sebesar 1.33E-06 juta rupiah dan sebaliknya.

Pengaruh diatas ini juga sesuai dengan penelitian oleh Yuda Satria (2016) yang menunjukan bahwa variabel upah minimum positif dan signifikan terhadap kemiskinan, sektor terbesar yang mendukung perekonomian di Indonesia adalah sektor pertanian, dimana sektor pertanian merupakan sektor informal.

Sektor informal tersebut masih belum bisa mensejahterakan masyarakat Indonesia. Peneliti menemukan hubungan positif upah minimum dengan jumlah penduduk miskin wajar karena mayoritas pekerjaan masyarakat Indonesia 
adalah bekerja pada sektor informal dan adanya faktor biaya sosial inflasi.

Banyaknya uang dicetak oleh pemerintah tidak menyebabkan upah bergantung pada uang dicetak. Jika pemerintah menurunkan inflasi dengan memperlambat tingkat pertumbuhan uang, para pekerja tidak melihat upah naik dengan cepat. Pada saat inflasi mengalami kelambatan, perusahaan akan sedikit menaikkan harga produk setiap tahunnya dan para pekerja menerima upah yang lebih kecil.

\section{PENUTUP}

Dari hasil sebelumnya, penulis dapat menarik beberapa kesimpulan mengenai tingkat pengangguran terbuka, indeks pembangunan manusia, dan upah minimum terhadap jumlah penduduk miskin di Indonesia. Kesimpulan yang dapat diambil adalah sebagai berikut:

TPT dan Jumlah Penduduk Miskin. Dari tabel 1 dapat dilihat bahwa TPT positif dan signifikan terhadap (Y). Nilai koefisien TPT sebesar 0,073014 memiliki arti bahwa setiap kenaikan TPT sebesar 1 persen dapat meningkatkan (Y) sebesar 0,073014 persen dan sebaliknya.

IPM dan Jumlah Penduduk Miskin. Dari tabel 1 menunjukkan IPM negatif dan signifikan terhadap (Y). Nilai koefisien IPM sebesar 0,865177, setiap peningkatan IPM sebesar 1 persen dapat megurangi (Y) sebesar 0,865177 persen dan sebaliknya.

Upah Minimum dan Jumlah Penduduk Miskin. Dari tabel 1 menunjukkan upah minimum positif dan signifikan terhadap (Y). Nilai koefisien upah minimum sebesar 1.33E-06, setiap kenaikan upah minimum sebesar 1 juta rupiah maka dapat meningkatkan (Y) sebesar 1.33E-06 juta rupiah dan sebaliknya.

Berdasarkan hasil penelitian maka saran yang disampaikan yaitu pemerintah diharapkan tanggap dengan permasalahan kemiskinan, tingkat pengangguran terbuka, indeks pembangunan manusia, dan upah minimum. Bagaimanapun hal tersebut menjadi tanggung jawab negara. Peneliti berikutnya supaya dapat menganalisis variabel-variabel lainnya yang dapat mempengaruhi kemiskinan. Oleh karenanya diperlukan penelitian mendalam 
dengan data dan metode yang lebih lengkap sehingga dapat menyempurnakan hasil penelitian yang telah ada.

\section{DAFTAR PUSTAKA}

BPS Indonesia. 2015. Data dan Informasi IPM Menurut Provinsi 1996-2013. Jakarta: BPS Indonesia.

------------------. 2016. Data dan
Informasi IPM Menurut Provinsi 2010-2015. Jakarta: BPS Indonesia.

2013. Data dan Informasi Jumlah Penduduk Miskin 2007-2012. Jakarta: BPS Indonesia.

Informasi Jumlah Penduduk
Miskin 2013-2016. Jakarta:
BPS Indonesia.
Informasi TPT Menurut
Provinsi 1986-2016. Jakarta:
BPS Indonesia.

2017. Data dan Informasi Upah Minimum Menurut Provinsi 1997-2016. Jakarta: BPS Indonesia.

-------------------. 2016. Statistik Indonesia 2016. Jakarta: BPS Indonesia.

Mufid, Fatkhul Cholili. 2014. Analisis Pengaruh Pengangguran, PDRB, dan IPM Terhadap Jumlah Penduduk Miskin. Malang: Universitas Brawijaya.

Nasir, M. 2008. Metode Penelitian. Jakarta: Ghalia.

Sugiyono. 2011. Statistika untuk Penelitian. Bandung: Alfabeta.

Sukirno, Sadono. 1997. Pengantar Teori Makroekonomi. Jakarta: Raja Grafindo Persada.

Yuda, Satria. 2016. Pengaruh Upah Minimum dan Distribusi Pendapatan Terhadap Jumlah Penduduk Miskin Jatim Tahun 2010-2014. Malang: Universitas Muhammadiyah Malang. 